$\begin{array}{ll}\text { Research Square } & \begin{array}{l}\text { Preprints are preliminary reports that have not undergone peer review. } \\ \text { They should not be considered conclusive, used to inform clinical practice, } \\ \text { or referenced by the media as validated information. }\end{array}\end{array}$

\title{
Accelerated Lower Leg Fracture Healing in Traumatic Brain Injury in Accordance With Increased Hematoma Formation
}

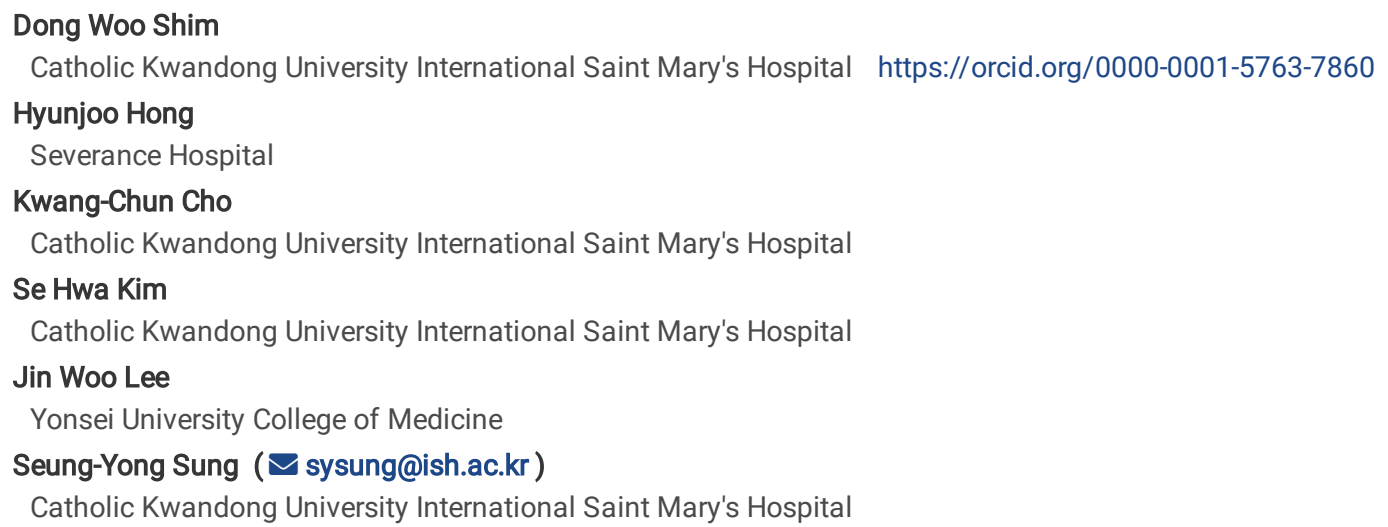

\section{Research article}

Keywords: traumatic brain injury, fracture healing, callus formation, hematoma

Posted Date: October 13th, 2021

DOI: https://doi.org/10.21203/rs.3.rs-948393/v1

License: (c) (i) This work is licensed under a Creative Commons Attribution 4.0 International License. Read Full License 


\section{Abstract}

\section{Background}

Traumatic brain injury (TBI) has been known to accelerate bone healing. Many cells and molecules have been investigated but the exact mechanism is still unknown. We aimed to investigate the effect of TBI on fracture healing regarding accelerated hematoma formation.

\section{Methods}

We retrospectively investigated patients who were surgically treated for lower leg fractures and who showed secondary bone healing. Patients with and without TBI were divided for comparative analyses. Radiological parameters were time to bridging callus formation and the largest callus ratio during follow-up. Preoperative levels of complete blood count and chemical battery within 3 days from trauma were measured in all patients. Subgroup division regarding age, gender, open fracture, concomitant fracture and severity of TBI were compared.

\section{Results}

We included 48 patients with a mean age of 44.9 (range, 17 - 78), of whom 35 patients (72.9\%) were male. There were 12 patients with TBI (Group 1 ) and 36 patients without TBI (Group 2). Group 1 showed shorter time to callus formation $(P<0.001)$, thicker callus ratio $(P=0.015)$, leukocytosis and lymphocytosis $(P \leq 0.028)$, and lower red blood cell counts $(R B C s)$, hemoglobin, and hematocrit $(P<0.001)$. Aging and severity of TBI were correlated with time to callus formation and callus ratio $(P \leq 0.003)$ while gender, open fracture, and concomitant fracture were unremarkable.

\section{Conclusion}

Lower leg fractures with TBI showed accelerated bone healing and superior measurements associated with hematoma formation (lymphocytes, RBCs, hemoglobin, hematocrit). Promoted fracture healing in TBI was correlated with the enhanced proinflammatory state.

Level of Evidence: Case control study; III

\section{Background}

After debatable results of traumatic brain injury (TBI) and accelerated fracture healing of earlier studies, many preclinical and clinical following studies supported that TBI is associated with rapid bone healing. $[3,9,12,29]$ Various materials from cytokine and growth factors to genes and hormones have been investigated as candidate substances associated with TBI but the mechanism has not been fully understood.[12, 13, 20]

Fracture healing comprises of inflammatory phase, fibrovascular phase, bone formation phase, and remodeling phase. Inflammatory phase starts with fibrin-rich hematoma formation from shearing of intracortical, endosteal, and periosteal vessels.[11] Chemokines from activated platelets within the hematoma accelerate the migration of neutrophils and macrophages to the fracture site.[2] These cells remove devitalized tissue around the fracture site, promote recruiting inflammatory cells and successively progenitor cells from the bone marrow, periosteum, soft tissue and systemic circulation.[1, 17]

Previous clinical studies have shown promoted osteogenic effect in TBI, but little has been studied through blood test results. Cadosch et al. investigated the human fetal osteoblastic (hFOB) cell and other biochemical markers including C-reactive protein, alkaline phosphatase, calcium, phosphate, and parathyroid hormone in long bone fracture patients with and without TBI. They showed higher proliferation of hFOB cells in TBI group whereas other biochemical markers showed unremarkable results.[3] A recent preclinical study reported that TBI alters the local neuroinflammatory state to accelerate early fracture healing.[19] They showed strong positive relationship between hematoma formation and fracture healing. Therefore, this study was designed to investigate the effect of TBI on fracture healing in patients with lower leg fractures and compare the laboratory tests regarding hematoma formation between the patients with and without TBI.

\section{Methods}

We retrospectively investigated 512 consecutive patients who were treated for lower leg fractures from February 2014 to January 2020 in our institution. We included patients between 17 and 80 years of age, who underwent plate fixation for comminuted fractures and showed secondary bone healing. Patients with primary bone healing without callus formation, fixated with other than plate such as intramedullary nail or screws only, severe open fracture (Gustilo-Anderson type $\geq \mathrm{III}$ ), insufficient follow-up period shorter than 1 year and underlying conditions that could impair bone healing (diabetes more than 10 years, cancer, organ transplantation, chronic renal failure, prolonged use of steroid and etc.) were excluded. Brain injury was evaluated with Glasgow Coma Scale (GCS) clinically when patients showed any kind of neurological impairments and brain computed tomography (CT) was checked subsequently. The type and extent of brain hemorrhage was assessed via CT scans and were scored according to Marshall classification system by a radiologist.[18] Neurosurgeons decided whether to evacuate the hematoma depending on the amount of intracranial hemorrhage. Patients were divided into two groups if they accompanied moderate to severe TBI (GCS $\leq 12)$ or not.

\section{Radiological and clinical outcomes}

The patient data included general demographic data, lower leg fracture type, targeting site for measurement either on tibia or fibula, concomitant fracture, performance of external fixation or not, and presence of open fracture. Patients were assessed at 6 weeks, 3 months, 6 months, and 12 months 
postoperatively with anteroposterior, lateral, and both oblique radiographs. Main radiologic outcome measures included time to bridging callus formation and the widest callus ratio during follow-up. Time to bridging callus formation was defined as the first appearance of the callus either on anteroposterior, lateral, or both oblique radiographs and the callus ratio was measured using the method previously described by Spencer (Fig 1.).[25] A blinded radiologist assessed these radiologic parameters.

Laboratory tests were obtained from all patients as soon as possible after visiting the hospital within 3 days from trauma. The levels of complete blood count (CBC), chemical battery including alkaline phosphatase (ALP), calcium, phosphate and C-reactive protein (CRP) were measured in all collected samples.

\section{Statistical analyses}

Patient characteristics are presented as mean (SD) or count (percentage). Statistical analysis was performed using the commercial software SPSS (version 21.0; IBM Corp, Armonk, NY). Mann-Whitney test, Fisher's exact test, and linear by linear association were used for statistical analyses to compare the two groups. Correlations among the radiologic and laboratory parameters with age were examined using the Spearman correlation coefficient test. Spearman's rho was interpreted as little $( \pm<0.3)$, low $( \pm 0.3-0.5)$, moderate $( \pm 0.5-0.7)$, high $( \pm 0.7-0.9)$, and very high $( \pm>0.9)$. [21] A $P$ value of $<0.05$ was considered statistically significant.

\section{Results}

We included 48 patients with a mean age of 44.9 (range, 17 - 78), of whom 35 patients (72.9\%) were male. There were 12 patients with TBI (Group 1 ) and 36 patients without TBI (Group 2). In Group 1, mean GCS was 6.2 (range, 3 - 12); there were 4 patients with subdural hemorrhage, 2 patients with epidural hemorrhage and 6 patients with combined injuries ( 3 with intracerebral and subarachnoid, 2 with subdural and subarachnoid, 1 with intracerebral, subarachnoid, and intraventricular hemorrhages). None of them expired during follow-up (mean 32.4 months, range 12 - 60). Four patients underwent burr hole trephinations. Six patients were grade 2, 2 patients were grade 3 , and 4 patients were grade 5 according to the Marshall classification of TBI. Patient characteristics between the groups are summarized in Table 1.

Table 1

Patient characteristics of lower leg fractures with and without traumatic brain injury

\begin{tabular}{|c|c|c|c|}
\hline & Group $1(\mathrm{~N}=12)$ & Group $2(\mathrm{~N}=36)$ & $P$ value \\
\hline Age & $41.5(14.2)$ & $46.1(15.4)$ & 0.294 \\
\hline Gender (Male, \%) & $10(83.3)$ & $25(69.4)$ & 0.469 \\
\hline AO classification $(\mathrm{n}, \%)$ & & & 0.130 \\
\hline $42 \mathrm{~B}$ & - & $3(8.3)$ & \\
\hline $42 \mathrm{C}$ & - & $1(2.8)$ & \\
\hline $43 \mathrm{~A}$ & $6(50)$ & $21(58.3)$ & \\
\hline $43 C$ & $6(50)$ & $11(30.6)$ & \\
\hline Callus measuring site (tibia: fibula, \% of tibia) & 4: $8(33.3)$ & 16: $20(44.4)$ & 0.503 \\
\hline Open fracture (Yes, \%) & - & $4(11.1)$ & 0.560 \\
\hline External fixation (Yes, \%) & $2(16.7)$ & $10(27.8)$ & 0.703 \\
\hline Concomitant fracture lesion (Yes, \%) & $12(100)$ & $4(11.1)$ & $0.001^{*}$ \\
\hline Skull & 10 & - & \\
\hline Spine & 6 & - & \\
\hline Facial bone & 5 & - & \\
\hline Rib & 4 & - & \\
\hline Clavicle & 2 & 1 & \\
\hline Forearm & 3 & 1 & \\
\hline Femur & 2 & 2 & \\
\hline Contralateral lower leg & - & 2 & \\
\hline \multicolumn{4}{|l|}{ Data are mean (SD) or $\mathrm{n}(\%)$. } \\
\hline *Statistically significant $(P<0.05)$ & & & \\
\hline
\end{tabular}


All patients obtained bone union within 12 months. Group 1 showed shorter time to callus formation $(P<0.001)$ and thicker callus ratio $(P=0.015)$ than Group 2. In addition Group 1 had higher WBC $(P=0.028)$ and lymphocyte count $(P=0.025)$, and lower red blood cell counts $(R B C s)$, hemoglobin, hematocrit $(P<0.001)$ compared to Group 2. Calcium level was significantly lower whereas phosphate was significantly higher in Group 1 . Other laboratory markers were unremarkable. (Table 2)

Table 2

Comparisons of radiological outcomes and laboratory tests between groups

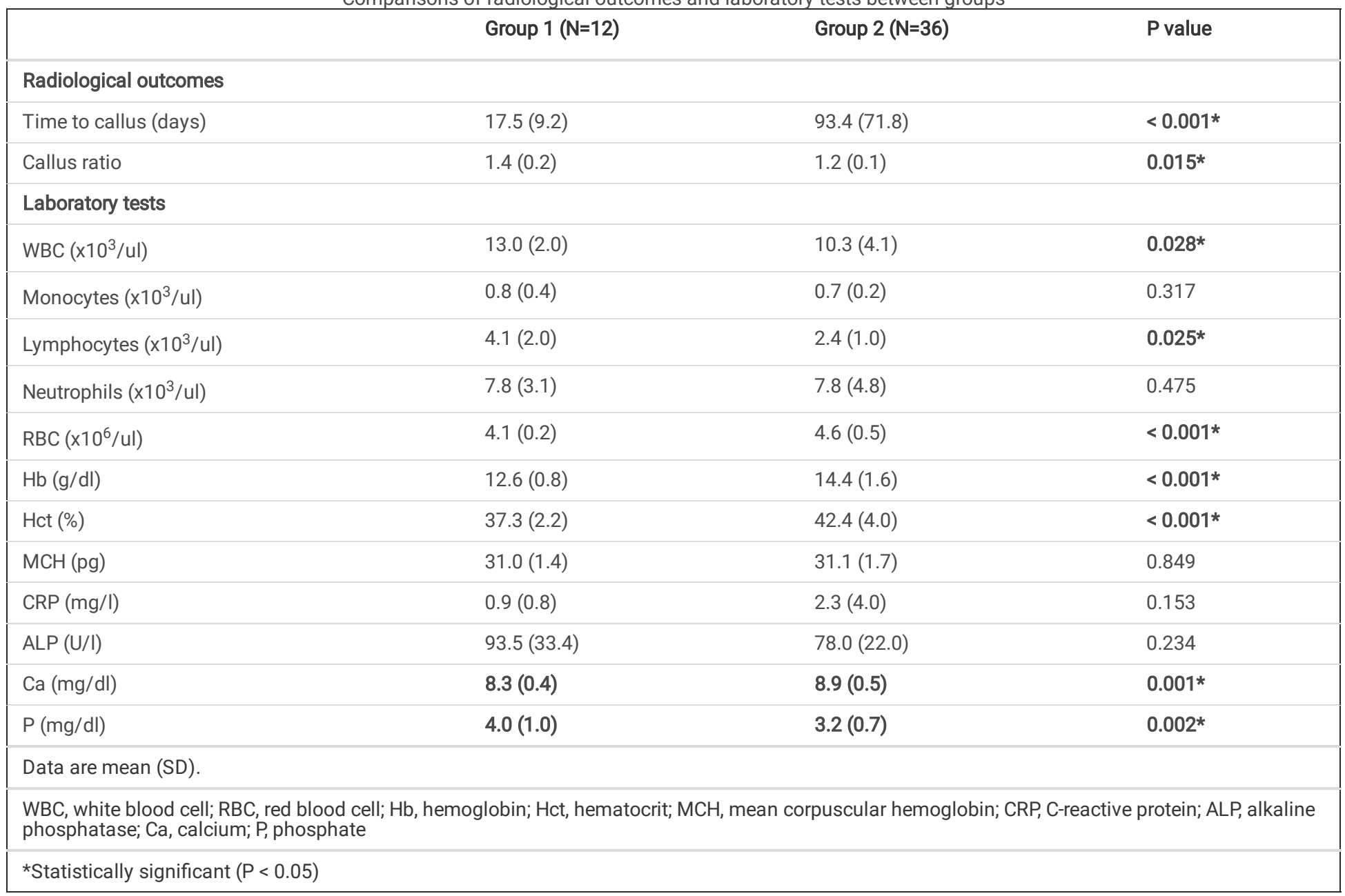

To clarify the effects of open fracture, gender, and other concomitant fracture on the callus formation, we divided the patients into two groups according to each nominal scale and compared them using Fisher's exact test. There were no significant differences in radiological outcomes among groups divided by open fracture, gender, and concomitant fracture. RBC profiles were significantly higher in groups with open fracture and male. WBC profile and ALP tended to be higher in the male group. (Table 3) 
Table 3

Comparisons of radiological outcomes and laboratory tests between groups regarding open fracture, gender, and concomitant fracture

\section{Whole groups}

\section{Group 2 only}

\begin{tabular}{|c|c|c|c|c|c|c|c|c|c|}
\hline & $\begin{array}{l}\text { Without open } \\
\text { fracture }(n=44)\end{array}$ & $\begin{array}{l}\text { With open } \\
\text { fracture }(n=4)\end{array}$ & $\begin{array}{l}\mathrm{P} \\
\text { value }\end{array}$ & $\begin{array}{l}\text { Male } \\
(n=35)\end{array}$ & $\begin{array}{l}\text { Female } \\
(n=13)\end{array}$ & $\begin{array}{l}\mathrm{P} \\
\text { value }\end{array}$ & $\begin{array}{l}\text { Without } \\
\text { concomitant } \\
\text { fracture }(n=32)\end{array}$ & $\begin{array}{l}\text { With concomitant } \\
\text { fracture }(n=4)\end{array}$ & $\begin{array}{l}P \\
\text { value }\end{array}$ \\
\hline \multicolumn{10}{|l|}{$\begin{array}{l}\text { Radiological } \\
\text { outcomes }\end{array}$} \\
\hline $\begin{array}{l}\text { Time to } \\
\text { callus (days) }\end{array}$ & 75.1 (71.6) & $81.3(71.6)$ & 0.900 & $\begin{array}{l}75.3 \\
(75.2)\end{array}$ & $\begin{array}{l}76.5 \\
(60.8)\end{array}$ & 0.651 & $95.0(74.7)$ & 77.7 (34.5) & 0.366 \\
\hline Callus ratio & $1.2(0.2)$ & $1.2(0.0)$ & 0.375 & $\begin{array}{l}1.3 \\
(0.2)\end{array}$ & $\begin{array}{l}1.2 \\
(0.1)\end{array}$ & 0.112 & $1.2(0.1)$ & $1.2(0.1)$ & 0.827 \\
\hline \multicolumn{10}{|l|}{$\begin{array}{l}\text { Laboratory } \\
\text { tests }\end{array}$} \\
\hline $\begin{array}{l}\text { WBC } \\
\left(x 10^{3} / u l\right)\end{array}$ & $10.5(3.6)$ & $13.2(5.8)$ & 0.585 & $\begin{array}{l}11.6 \\
(3.6)\end{array}$ & $\begin{array}{l}8.6 \\
(3.5)\end{array}$ & 0.055 & $10.1(4.2)$ & $11.6(4.1)$ & 0.208 \\
\hline $\begin{array}{l}\text { Monocytes } \\
\left(x 10^{3} / \mathrm{ul}\right)\end{array}$ & $0.7(0.3)$ & $0.8(0.4)$ & 0.577 & $\begin{array}{l}0.8 \\
(0.3)\end{array}$ & $\begin{array}{l}0.5 \\
(0.2)\end{array}$ & $0.007^{*}$ & $0.6(0.2)$ & $0.7(0.3)$ & 0.716 \\
\hline $\begin{array}{l}\text { Lymphocytes } \\
\left(\mathrm{x} 10^{3} / \mathrm{ul}\right)\end{array}$ & $2.9(1.6)$ & $2.4(0.7)$ & 0.986 & $\begin{array}{l}3.2 \\
(1.6)\end{array}$ & $\begin{array}{l}1.9 \\
(0.6)\end{array}$ & $0.006 *$ & $2.4(0.9)$ & $3.0(2.3)$ & 0.790 \\
\hline $\begin{array}{l}\text { Neutrophils } \\
\left(x 10^{3} / \mathrm{ul}\right)\end{array}$ & $7.6(4.3)$ & $9.8(5.4)$ & 0.375 & $\begin{array}{l}8.0 \\
(4.1)\end{array}$ & $\begin{array}{l}7.1 \\
(5.1)\end{array}$ & 0.302 & $6.9(4.0)$ & $7.7(4.6)$ & 0.292 \\
\hline $\operatorname{RBC}\left(x 10^{6} / \mathrm{ul}\right)$ & $4.5(0.5)$ & $5.0(0.3)$ & $0.026^{*}$ & $\begin{array}{l}4.6 \\
(0.5)\end{array}$ & $\begin{array}{l}4.2 \\
(0.3)\end{array}$ & $0.010 *$ & $4.6(0.5)$ & $4.7(0.5)$ & 0.716 \\
\hline $\mathrm{Hb}(\mathrm{g} / \mathrm{dl})$ & $13.7(1.5)$ & $16.2(1.1)$ & $0.003^{*}$ & $\begin{array}{l}14.4 \\
(1.7)\end{array}$ & $\begin{array}{l}12.8 \\
(0.9)\end{array}$ & $0.002^{*}$ & $14.4(1.5)$ & $14.1(2.2)$ & 0.511 \\
\hline Hct (\%) & $40.5(4.2)$ & $46.5(2.7)$ & $0.007^{*}$ & $\begin{array}{l}42.2 \\
(4.4)\end{array}$ & $\begin{array}{l}38.1 \\
(2.7)\end{array}$ & $0.002^{*}$ & $42.6(3.9)$ & $41.3(5.5)$ & 0.610 \\
\hline $\mathrm{MCH}(\mathrm{pg})$ & $30.8(1.5)$ & $32.4(1.7)$ & 0.063 & $\begin{array}{l}31.2 \\
(1.6)\end{array}$ & $\begin{array}{l}30.2 \\
(1.1)\end{array}$ & $0.043^{*}$ & $31.2(1.6)$ & 29.8 (1.7) & 0.248 \\
\hline $\mathrm{CRP}(\mathrm{mg} / \mathrm{l})$ & $2.1(3.7)$ & $0.9(0.4)$ & 0.985 & $\begin{array}{l}1.4 \\
(1.6)\end{array}$ & $\begin{array}{l}3.6 \\
(6.1)\end{array}$ & 0.893 & $2.5(4.2)$ & $0.6(0.2)$ & 0.248 \\
\hline $\operatorname{ALP}(\mathrm{U} / \mathrm{I})$ & $83.7(27.0)$ & $78.8(16.2)$ & 0.925 & $\begin{array}{l}88.2 \\
(27.3)\end{array}$ & $\begin{array}{l}70.4 \\
(18.2)\end{array}$ & $0.048^{*}$ & $78.8(22.0)$ & $69.7(25.3)$ & 0.610 \\
\hline $\mathrm{Ca}(\mathrm{mg} / \mathrm{dl})$ & $8.7(0.6)$ & $8.9(0.6)$ & 0.762 & $\begin{array}{l}8.8 \\
(0.6)\end{array}$ & $\begin{array}{l}8.8 \\
(0.5)\end{array}$ & 0.989 & $9.0(0.5)$ & $8.2(0.5)$ & 0.037 * \\
\hline$P(\mathrm{mg} / \mathrm{dl})$ & $3.5(0.8)$ & $2.9(0.8)$ & 0.227 & $\begin{array}{l}3.4 \\
(1.0)\end{array}$ & $\begin{array}{l}3.6 \\
(0.5)\end{array}$ & 0.328 & $3.2(0.7)$ & $3.4(0.7)$ & 0.657 \\
\hline \multicolumn{10}{|c|}{ Data are mean (SD). } \\
\hline \multicolumn{10}{|c|}{$\begin{array}{l}\text { WBC, white blood cell; RBC, red blood cell; Hb, hemoglobin; Hct, hematocrit; MCH, mean corpuscular hemoglobin; CRP, C-reactive protein; ALP, alkaline } \\
\text { phosphatase; Ca, calcium; P, phosphate }\end{array}$} \\
\hline \multicolumn{10}{|c|}{ *Statistically significant $(P<0.05)$} \\
\hline
\end{tabular}

In addition, we intended to assess the effects of age, number of intracranial hemorrhagic lesion, and Marshall classification on the outcomes. Age showed low negative correlation with callus ratio. As number of intracranial hemorrhagic lesion increased, callus ratio and WBC count significantly decreased with moderate correlation $(P=0.003$ and $P=0.006$, respectively). GCS tended to be negatively correlated with callus ratio but was not statistically significant $(P=0.076)$. Marshall classification positively correlated with time to callus, hemoglobin, hematocrit, and $\mathrm{MCH}$ whereas it was negatively correlated with calcium and phosphate. The correlation between Marshall classification and radiological and laboratory parameters were moderate to very high. (Table 4) 
Table 4

Spearman's correlation tests of age, number of traumatic brain injuries, and Marshall classification with outcomes and of radiological outcome with laboratory tests.

\begin{tabular}{|c|c|c|c|c|c|c|c|c|c|c|c|c|}
\hline & \multicolumn{6}{|c|}{ Whole groups } & \multicolumn{6}{|c|}{ Group 1 only } \\
\hline & $\begin{array}{l}\text { Rho } \\
\text { (age) }\end{array}$ & $\begin{array}{l}\mathrm{P} \\
\text { value }\end{array}$ & $\begin{array}{l}\text { Rho } \\
\text { (time } \\
\text { to } \\
\text { callus) }\end{array}$ & $P$ value & $\begin{array}{l}\text { Rho } \\
\text { (callus } \\
\text { ratio) }\end{array}$ & $\begin{array}{l}\mathrm{P} \\
\text { value }\end{array}$ & $\begin{array}{l}\text { Rho } \\
\text { (number } \\
\text { of } \\
\text { traumatic } \\
\text { brain } \\
\text { injuries) }\end{array}$ & $\begin{array}{l}\mathrm{P} \\
\text { value }\end{array}$ & $\begin{array}{l}\text { Rho } \\
\text { (GCS) }\end{array}$ & $P$ value & $\begin{array}{l}\text { Rho (Marshall } \\
\text { classification) }\end{array}$ & $P$ value \\
\hline \multicolumn{13}{|l|}{$\begin{array}{l}\text { Radiological } \\
\text { outcomes }\end{array}$} \\
\hline $\begin{array}{l}\text { Time to } \\
\text { callus (days) }\end{array}$ & -0.088 & 0.553 & - & & -0.089 & 0.549 & 0.297 & 0.348 & -0.164 & 0.593 & 0.939 & $<0.001^{*}$ \\
\hline Callus ratio & -0.458 & $0.001^{*}$ & -0.089 & 0.549 & - & & -0.772 & $0.003^{*}$ & -0.508 & 0.076 & -0.154 & 0.632 \\
\hline \multicolumn{13}{|l|}{$\begin{array}{l}\text { Laboratory } \\
\text { tests }\end{array}$} \\
\hline $\begin{array}{l}\text { WBC } \\
\left(x 10^{3} / u l\right)\end{array}$ & -0.059 & 0.692 & -0.109 & 0.460 & 0.186 & 0.204 & -0.741 & $0.006 *$ & -0.073 & 0.814 & 0.123 & 0.702 \\
\hline $\begin{array}{l}\text { Monocytes } \\
\left(x 10^{3} / \mathrm{ul}\right)\end{array}$ & -0.107 & 0.469 & -0.129 & 0.381 & 0.236 & 0.106 & -0.093 & 0.775 & -0.486 & 0.092 & -0.062 & 0.849 \\
\hline $\begin{array}{l}\text { Lymphocytes } \\
\left(\mathrm{x} 10^{3} / \mathrm{ul}\right)\end{array}$ & -0.062 & 0.676 & -0.169 & 0.252 & 0.199 & 0.175 & -0.031 & 0.924 & 0.106 & 0.730 & -0.031 & 0.924 \\
\hline $\begin{array}{l}\text { Neutrophils } \\
\left(\mathrm{x} 10^{3} / \mathrm{ul}\right)\end{array}$ & 0 & 1.000 & 0.021 & 0.888 & 0.022 & 0.882 & -0.278 & 0.382 & -0.017 & 0.957 & 0.123 & 0.702 \\
\hline $\begin{array}{l}\text { RBC } \\
\left(x 10^{6} / u l\right)\end{array}$ & -0.185 & 0.209 & 0.441 & $0.002^{\star \star}$ & -0.177 & 0.230 & -0.063 & 0.847 & 0.989 & $<0.001^{\star \star}$ & -0.313 & 0.322 \\
\hline $\mathrm{Hb}(\mathrm{g} / \mathrm{dl})$ & -0.101 & 0.495 & 0.442 & $0.002^{\star \star}$ & -0.104 & 0.483 & -0.123 & 0.702 & 0.464 & 0.110 & 0.617 & $0.033^{*}$ \\
\hline Hct (\%) & -0.104 & 0.481 & 0.465 & $0.001^{\star *}$ & -0.129 & 0.384 & -0.123 & 0.702 & 0.464 & 0.110 & 0.617 & $0.033^{*}$ \\
\hline $\mathrm{MCH}(\mathrm{pg})$ & 0.206 & 0.159 & 0.009 & 0.950 & 0.058 & 0.696 & 0.216 & 0.500 & -0.390 & 0.188 & 0.925 & $<0.001^{* \star}$ \\
\hline $\mathrm{CRP}(\mathrm{mg} / \mathrm{l})$ & 0.120 & 0.417 & -0.015 & 0.921 & -0.126 & 0.395 & 0.185 & 0.565 & -0.291 & 0.336 & -0.370 & 0.236 \\
\hline $\operatorname{ALP}(\mathrm{U} / \mathrm{I})$ & -0.025 & 0.864 & -0.283 & 0.052 & -0.064 & 0.666 & 0.062 & 0.849 & 0.078 & 0.800 & -0.401 & 0.196 \\
\hline $\mathrm{Ca}(\mathrm{mg} / \mathrm{dl})$ & -0.153 & 0.315 & 0.345 & 0.020 * & -0.373 & $0.012^{*}$ & -0.204 & 0.526 & 0.537 & 0.059 & -0.751 & $0.005^{\star *}$ \\
\hline$P(\mathrm{mg} / \mathrm{dl})$ & -0.177 & 0.245 & -0.492 & $0.001 * *$ & 0.180 & 0.237 & -0.278 & 0.382 & -0.156 & 0.610 & -0.833 & $0.001 * *$ \\
\hline
\end{tabular}

When we focused on the correlation between radiological outcomes and laboratory test, the two radiological outcomes had no significant correlation with each other (Spearman's rho $=-0.089, \mathrm{P}=0.549$ ). Time to callus formation was positively correlated with RBC profile except for MCH and calcium whereas it was negatively correlated with phosphate significantly. On the contrary, callus ratio was negatively correlated with calcium level. (Table 4)

\section{Discussion}

We reaffirmed that TBI have accelerated callus formation and fracture healing in patients with lower leg fractures. Time to bridging callus formation and callus ratio were significantly superior in Group 1 despite the lower calcium level. Leukocytosis and lymphocytosis were predominant and RBC profiles including hemoglobin and hematocrit were lower in Group 1. Open fracture, gender, GCS, and presence of concomitant fracture did not show significant differences in radiological outcomes. Increasing age and number of intracranial hemorrhagic lesion were negatively correlated with callus ratio. Higher Marshall classification category showed very strongly positive correlation with time to callus formation.

Garland and Dowling reported absent correlation between TBI and accelerated tibial fracture healing as a pioneer study.[7] However, it contained mixed cohort of patients including severe open fractures and various surgical or conservative treatment modalities that could have made it inconclusive. Following clinical studies showed an obvious osteogenic effect of TBI from long bones to flat bones. $[3,8,9,14,29]$ However, few factors have been investigated as candidate substances to explain the phenomenon such as runt-related transcription factor 2, serine protease 7, cathepsin $\mathrm{K}$, and hFOB1.19 cell line.[3, 8] Recently, Morioka et al. reported a neuroinflammatory response in polytrauma with TBI in rodent model.[19] They showed that 
hematoma formation inferred from systemic lymphocytes, RBCs, hemoglobin and hematocrit was strongly positively related with fracture healing using multivariate principal component analysis. The first stage of bone healing is the inflammatory phase. The inflammatory phase is mainly mediated by fracture hematoma consisting of blood cells, mesenchymal stem cells, fibroblasts and etc., and can last for about 5 days.[11, 12] These cells promote gathering of inflammatory cells via release of pro-inflammatory cytokines such as tumor necrosis factor-alpha, interleukins 1 and 6 , and subsequent growth factors. $[1,16,17]$ A closer look of the Morioka's study reveals that TBI additional to tibia fracture showed increased WBCs, monocytes, and lymphocytes and decreased RBC profiles compared to fracture only after 5 days from injury.[19] These changes gradually recovered to normal range after 15 days from injury. Our results are consistent with results of the previous studies in that Group 1 showed significant elevation of WBC and lymphocyte $(P \leq 0.028)$ and decrease of RBC, hemoglobin, and hematocrit $(P<0.001)$ at admission although there was lack of further laboratory tests. Larger hematomas in Group 1 might have accelerated the proinflammatory response to secondary bone healing.

Moderate to severe TBI (GCS $\leq 12)$ is well known to cause pituitary or hypothalamic dysfunction.[15] Yang et al. showed promoted callus formation in the fracture with TBI group as well. However, when they subdivided the TBI group to GCS $\leq 8$ and GCS $>8$, there was no significant differences in time to callus formation and callus thickness $(P=0.521, P=0.153)$.[29] Several hormones such as leptin, prolactin, calcitonin-gene-related peptide from cerebral dysfunction and damage to blood brain barrier are believed to be the possible factors of accelerated bone healing in TBI despite that accurate mechanisms remain uncertain.[5, 6, 10, 12, 22, 24, 26-28, 30,31] Morioka et al. revealed inverse correlation of fracture callus with brain lesion by analyzing total lesion volume and gross lesion area in TBI.[19] Cadosch et al. reported a negative linear relationship between GCS and callus ratio.[3] They showed that GCS was correlated with callus ratio $(P<0.05)$, time to union $(P=0.04)$, and proliferation rate of hFOB cells after 6 hours from injury $(P$ $=0.03)$. Similarly, this study also showed a significantly negative correlation between number of intracranial hemorrhagic lesion and callus ratio (Spearman's rho $=-0.772, \mathrm{P}=0.003)$, and a negative correlation tendency between GCS and callus ratio $($ Spearman's rho $=-0.508, \mathrm{P}=0.076)$. Interestingly, Marshall classification showed a very highly positive correlation with time to callus formation despite its negative correlation with calcium and phosphate levels (Spearman's rho $=0.939, \mathrm{P}<0.001$ ). Marshall classification places patients into one of six categories of increasing severity based on the findings on non-contrast brain CT scan.[18] It is primarily concerned with degree of swelling and presence and size of hemorrhage. Higher categories have worse prognosis and survival. Thus, it might be a more accurate assessment of suppression of brain function; therefore, it could be more related to callus formation. Following study of relationship between Marshall classification and bone healing in TBI with larger cohort would help assess the role of brain and estimate the accelerated fracture healing in TBI.

Aging showed a significantly negative correlation with callus ratio in this study (Spearman's rho $=-0.458, \mathrm{P}=0.001$ ). Increasing age has been well known to negatively affect the cellular and molecular processes of fracture healing throughout all phases.[4, 23] Intrinsic changes in stem cell population and microenvironmental changes that alter the biological activity of progenitor cells are the two aspects to potentially affect tissue regeneration.

The two radiological outcomes of time to callus formation and callus ratio did not significantly correlate with each other (Spearman's rho $=-0.089$, $\mathrm{P}=$ 0.549). Interestingly, time to callus formation was positively correlated with higher RBC profiles (Spearman's rho $=0.441-0.465, P \leq 0.002$ ). Rapid callus formation in general could be more related to the number of RBCs capable of exchanging oxygen and waste despite the low RBC profile in group 1 in this study. These conflicting results might indicate that several mechanisms including accelerated hematoma and brain dysfunction have blended effects in promoting fracture healing. Further study with serial laboratory tests would be helpful in distinguishing their effects. Male gender showed significantly superior monocytes, lymphocytes, RBC profiles, and ALP compared to female gender. However, there was no significant differences in the two radiological outcomes between each other. It is comparable to the results of a previous study in which there was no gender difference in fracture healing [29] Presence of open fracture below Gustilo type II did not significantly affect any radiological and laboratory tests.

This study has several limitations. First, despite that all patients in both groups were evaluated with the same postoperative follow-up protocol and were intended to be involved thoroughly, this study was a retrospective study which might have resulted in a possible selection bias. Second, the study population was relatively small, which could have decreased the statistical power of the results. We could have derived a more significant categories that might have correlated with each other such as GCS. Third, all patients lacked pre-trauma laboratory tests which could be the reference points for analyzing the hemoglobin down. In addition, there is a weak point that hemoglobin down contributed exclusively to the formation of fracture hematoma. However, factors which might have affected the difference of hemoglobin level such as aging and gender were not significantly different between the groups. A previous preclinical study has shown the systemic hemoglobin down as the hematoma formation.[19] Following study regarding these factors can derive further relationship between not only RBC profiles but also WBC profile including neutrophil and monocyte and accelerated fracture healing in TBI.

\section{Conclusion}

Lower leg fractures with TBI showed accelerated bone healing and superior measurements associated with hematoma formation (lymphocytes, RBCs, hemoglobin, hematocrit). Promoted fracture healing correlated with the promoted proinflammatory state.

\section{Declarations}

Ethics approval and consent to participate: This study was approved by the Catholic Kwandong University International St. Mary's Institutional Review Board (IS21RISI0066)

Consent for publication: Not applicable 
Availability of data and material: The datasets generated and analyzed during the current study are not publicly available but are available from the corresponding author on reasonable request.

Competing interests: Each author certifies that he or she has no commercial associations (e.g., consultancies, stock ownership, equity interest, patent/licensing arrangements, etc.) that might pose a conflict of interest in connection with the submitted article.

Funding: One of the authors (D.W.S.) has received funding from Basic Science Research Program through the National Research Foundation of Korea(NRF) funded by the Ministry of Science, ICT \& Future Planning(NRF-2019R1G1A1098885).

\section{Author contributions}

1. Conceptualization: Dong Woo Shim

2. Data curation: Dong Woo Shim, Kwang-Chun Cho

3. Formal analysis: Kwang-Chun Cho, Hyunjoo Hong

4. Funding acquisition: Dong Woo Shim

5. Investigation: Dong Woo Shim, Kwang-Chun Cho, Hyunjoo Hong

6. Methodology: Se Hwa Kim, Jin Woo Lee

7. Project administration: Jin Woo Lee, Seung-Yong Sung

8. Resources: Dong Woo Shim

9. Software: Dong Woo Shim, Kwang-Chun Cho

10. Supervision: Jin Woo Lee

11. Validation: Kwang-Chun Cho, Seung-Yong Sung, Se Hwa Kim

12. Visualization: Dong Woo Shim, Jin Woo Lee, Seung-Yong Sung

13. Writing - original draft: Dong Woo Shim

14. Writing - review \& editing: Seung-Yong Sung

Acknowledgements: None

\section{References}

1. Baht GS, Vi L, Alman BA. The Role of the Immune Cells in Fracture Healing. Curr Osteoporos Rep. 2018;16:138-45.

2. Bolander ME. Regulation of fracture repair by growth factors. Proc Soc Exp Biol Med. 1992;200:165-70.

3. Cadosch D, Gautschi OP, Thyer M, Song S, Skirving AP, Filgueira L, et al. Humoral factors enhance fracture-healing and callus formation in patients with traumatic brain injury. J Bone Joint Surg Am. 2009;91:282-8.

4. Clark D, Nakamura M, Miclau T, Marcucio R. Effects of Aging on Fracture Healing. Curr Osteoporos Rep. 2017;15:601-8.

5. Ducy P, Amling M, Takeda S, Priemel M, Schilling AF, Beil FT, et al. Leptin inhibits bone formation through a hypothalamic relay: a central control of bone mass. Cell. 2000;100:197-207.

6. Garbe A, Graef F, Appelt J, Schmidt-Bleek K, Jahn D, Lunnemann T, et al. Leptin Mediated Pathways Stabilize Posttraumatic Insulin and Osteocalcin Patterns after Long Bone Fracture and Concomitant Traumatic Brain Injury and Thus Influence Fracture Healing in a Combined Murine Trauma Model. Int J Mol Sci 2020;21.

7. Garland DE, Toder L. Fractures of the tibial diaphysis in adults with head injuries. Clin Orthop Relat Res 1980:198-202.

8. Gautschi OP, Cadosch D, Frey SP, Skirving AP, Filgueira L, Zellweger R. Serum-mediated osteogenic effect in traumatic brain-injured patients. ANZ J Surg. 2009;79:449-55.

9. Giannoudis PV, Mushtaq S, Harwood P, Kambhampati S, Dimoutsos M, Stavrou Z, et al. Accelerated bone healing and excessive callus formation in patients with femoral fracture and head injury. Injury. 2006;37(Suppl 3):18-24.

10. Hamrick MW, Pennington C, Newton D, Xie D, Isales C. Leptin deficiency produces contrasting phenotypes in bones of the limb and spine. Bone. 2004;34:376-83.

11. Hellwinkel JE, Miclau T 3rd, Provencher MT, Bahney CS, Working ZM. The Life of a Fracture: Biologic Progression, Healing Gone Awry, and Evaluation of Union. JBJS Rev. 2020;8:e1900221.

12. Hofman M, Koopmans G, Kobbe P, Poeze M, Andruszkow H, Brink PR, et al. Improved fracture healing in patients with concomitant traumatic brain injury: proven or not? Mediators Inflamm. 2015;2015:204842.

13. Huang H, Cheng WX, Hu YP, Chen JH, Zheng ZT, Zhang P. Relationship between heterotopic ossification and traumatic brain injury: Why severe traumatic brain injury increases the risk of heterotopic ossification. J Orthop Translat. 2018;12:16-25.

14. Huang W, Li Z, Li Z, Yang R. Does traumatic brain injury result in accelerated mandibular fracture healing? J Oral Maxillofac Surg. $2012 ; 70: 2135-42$.

15. Javed Z, Qamar U, Sathyapalan T. Pituitary and/or hypothalamic dysfunction following moderate to severe traumatic brain injury: Current perspectives. Indian J Endocrinol Metab. 2015;19:753-63.

16. Kolar P, Schmidt-Bleek K, Schell H, Gaber T, Toben D, Schmidmaier G, et al. The early fracture hematoma and its potential role in fracture healing. Tissue Eng Part B Rev. 2010;16:427-34. 
17. Loi F, Cordova LA, Pajarinen J, Lin TH, Yao Z, Goodman SB. Inflammation, fracture and bone repair. Bone. 2016;86:119-30.

18. Marshall LF, Marshall SB, Klauber MR, Van Berkum Clark M, Eisenberg H, Jane JA, et al. The diagnosis of head injury requires a classification based on computed axial tomography. J Neurotrauma. 1992;9(Suppl 1):287-92.

19. Morioka K, Marmor Y, Sacramento JA, Lin A, Shao T, Miclau KR, et al. Differential fracture response to traumatic brain injury suggests dominance of neuroinflammatory response in polytrauma. Sci Rep. 2019;9:12199.

20. Morley J, Marsh S, Drakoulakis E, Pape HC, Giannoudis PV. Does traumatic brain injury result in accelerated fracture. healing? Injury. 2005;36:363-8.

21. Rovai AP, Baker JD, Ponton MK. Social science research design and statistics: A practitioner's guide to research methods and IBM. SPSS: Watertree Press LLC; 2013.

22. Seemann R, Graef F, Garbe A, Keller J, Huang F, Duda G, et al. Leptin-deficiency eradicates the positive effect of traumatic brain injury on bone healing: histological analyses in a combined trauma mouse model. J Musculoskelet Neuronal Interact. 2018;18:32-41.

23. Shiu HT, Leung PC, Ko CH. The roles of cellular and molecular components of a hematoma at early stage of bone healing. J Tissue Eng Regen Med. 2018;12:e1911-e25.

24. Song Y, Bi L, Zhang Z, Huang Z, Hou W, Lu X, et al. Increased levels of calcitonin gene-related peptide in serum accelerate fracture healing following traumatic brain injury. Mol Med Rep. 2012;5:432-8.

25. Spencer RF. The effect of head injury on fracture healing. A quantitative assessment. J Bone Joint Surg Br. 1987;69:525-8.

26. Wei Y, Wang L, Clark JC, Dass CR, Choong PF. Elevated leptin expression in a rat model of fracture and traumatic brain injury. J Pharm Pharmacol. 2008;60:1667-72.

27. Wildburger R, Zarkovic N, Tonkovic G, Skoric T, Frech S, Hartleb M, et al. Post-traumatic hormonal disturbances: prolactin as a link between head injury and enhanced osteogenesis. J Endocrinol Invest. 1998;21:78-86.

28. Yan H, Zhang HW, Fu P, Liu BL, Jin WZ, Duan SB, et al. Leptin's effect on accelerated fracture healing after traumatic brain injury. Neurol Res. 2013;35:537-44.

29. Yang TY, Wang TC, Tsai YH, Huang KC. The effects of an injury to the brain on bone healing and callus formation in young adults with fractures of the femoral shaft. J Bone Joint Surg Br. 2012;94:227-30.

30. Zhang D, Zhang P, Wang Y, Han N, Tang C, Jiang B. The influence of brain injury or peripheral nerve injury on calcitonin gene-related peptide concentration variation and fractures healing process. Artif Cells Blood Substit Immobil Biotechnol. 2009;37:85-91.

31. Zhang JY, Yan GT, Liao J, Deng ZH, Xue H, Wang LH, et al. Leptin attenuates cerebral ischemia/reperfusion injury partially by CGRP expression. Eur J Pharmacol. 2011;671:61-9.

\section{Figures}
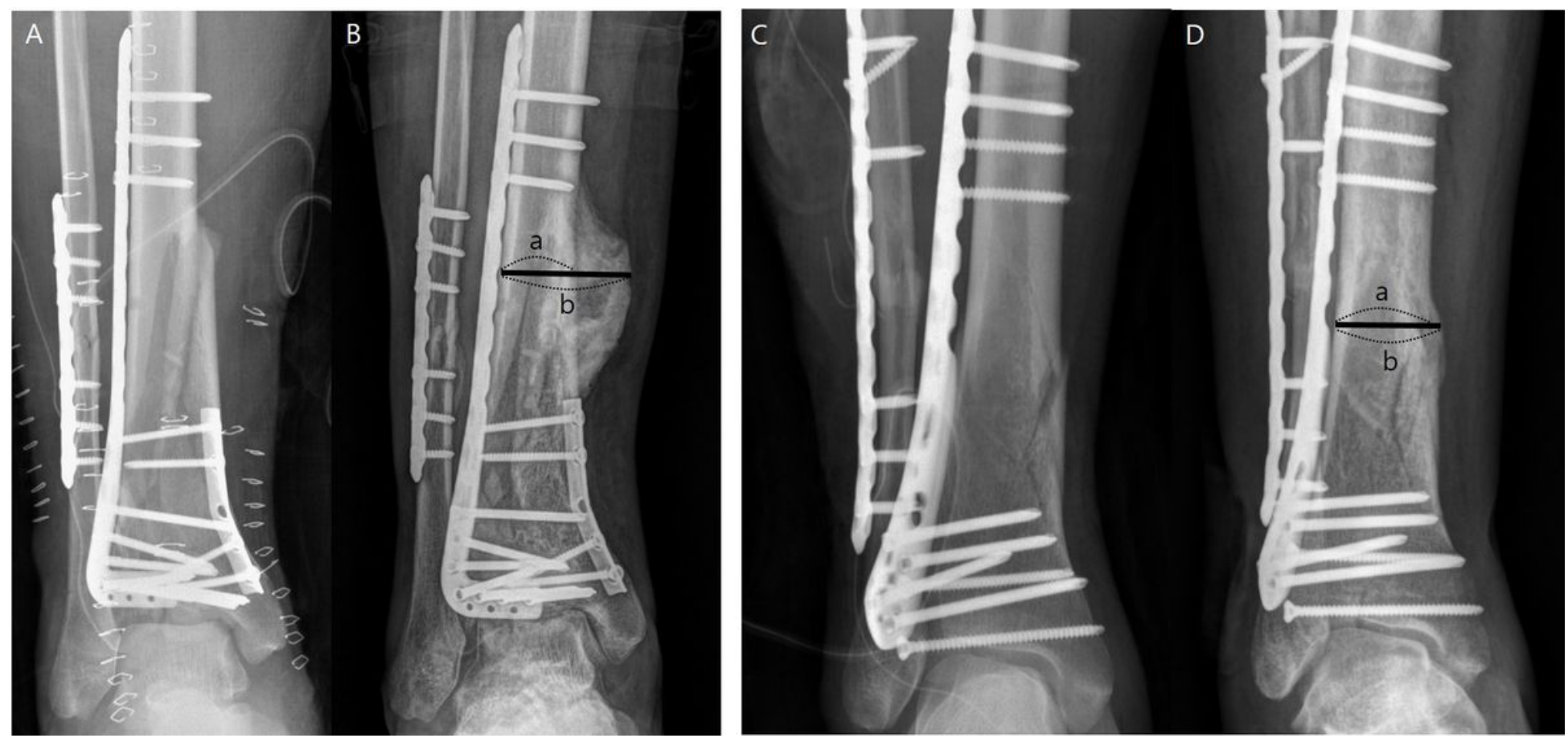

Figure 1

A, B) AP radiographs of a 33-year-old male with traumatic brain injury at immediate post-operation and at 6 months follow up. C, D) AP radiographs of a 56-year-old female without traumatic brain injury at immediate post-operation and at 3 months follow up. Callus ratio measuring method by Spencer $=$ 
b/a.

Page 10/10 